\title{
Learning Concentration Level of Students at Faculty of Nursing Universitas Padjadjaran (An Overview Of The Z Generation)
}

\author{
Asti Hanifah, Efri Widianti, Kurniawan Yudianto \\ Faculty of Nursing, Universitas Padjadjaran \\ Email:efri.widianti@unpad.ac.id
}

\begin{abstract}
Generation $\mathrm{Z}$ is a generation that has grown in the digital era and is dependent on the internet. One of the features of the internet that is most accessed by this generation is social media. Social media as the information source has a negative impact, especially related to academic processes in the university, namely the learning concentration disorder. Students as part of the $\mathrm{Z}$ gene is a population that uses various gadgets (gadgets), so that they are at risk of experiencing learning concentration disorders. The purpose of this study was to describe the level of concentration of learning in students of the Nursing Faculty of Padjadjaran University. This research is quantitative descriptive. The sample was taken using the proportionate stratified random sampling technique from the population of the Nursing Faculty of Padjadjaran University $(n=240)$. Data were collected using concentration learning questionnaires and analyzed descriptively. The results showed that 40 students $(16.7 \%)$ had low levels of learning concentration, 166 students $(69.2 \%)$ with moderate learning concentration levels and $23(14.2 \%)$ with high levels of learning concentration. The conclusion of this study is that most of the Nursing Faculty students of Padjadjaran University have a moderate level of learning concentration. It is recommended to apply varied methods and learning styles in learning activities so that the level of concentration of student learning can be increased.
\end{abstract}

Keywords: Learning concentration, nursing students, Z Generation. 
Asti Hanifah: Learning Concentration Level of Students

\section{Introduction}

$\mathrm{Z}$ generation is a technology generation, this generation is growing and developing in the digital era and is dependent on internetbased facilities, according to Tapscott (2008) generation $\mathrm{Z}$ has been introduced to the internet since childhood, therefore the $\mathrm{Z}$ generation is very good at accessing the internet. The internet is a medium and information media has many features that make it easier for users to get what they are looking for, one of them is through social media (Zuhra, 2017). Generation Z has a variety of characteristics that are quite different when compared to the previous generation. According to Pruitt (2017) and Sudrajat (2012), the characteristics of the Z generation include technology driven and social, very well versed in technology that is currently developing in the digital era, and some of them prefer digital conversations through social media rather than directly discussing specifically if you are in a different place. This generation tends to be difficult to keep away from gadgets, these gadgets are a source of knowledge and information.

Students in the university level are final teens in the phase of exploring experience (Puspitasari, 2017). Most of them are joined with organizations, committees, and other activities on campus. According to Sari and Lisiswanti (2017), these activities cause reducing their study time in the afternoon and evening and only having time for study during lectures. Lectures are the main time for them to study. Based on the characteristics of generation $\mathrm{Z}$ which tend to be technology driven and technologically fluent, this generation's learning style is more likely to use visual or image effects, and they have the effectiveness of noticing things for a short time. According to Lancaster (2002), generation $\mathrm{Z}$ tends to feel bored quickly when doing something both work and activity at the same time for a long time.

The use of gadgets and social media in generation $\mathrm{Z}$ has a positive and negative impact, especially in academic aspects (Wang, 2011). The positive impact is a medium of information, knowledge, and communication, while the negative impact causes symptoms of addiction to access social media and gadgets because of excessive and uncontrolled use (Young, 2017). The use of social media with high intensity can cause a decrease in concentration, a decrease in work productivity, and academic failure (Hakim \& Florencia, 2003).

One aspect that supports academic achievement is the level of concentration in learning. In the process of teaching and learning activities, concentration is needed to focus attention on a particular object. Reducing students' concentration of learning raises several disadvantages, for example achieving learning outcomes. Relationships in the current era determine the attitudes and behavior of individuals. Relationships are influenced by technological factors, namely the internet, especially social media. Rahmayani (2017) said that one of the factors that influence the concentration of learning is the use of mobile phones. The gadget is used mostly for accessing social media. Social media has an addictive user effect, someone who is addicted will continue to focus his mind and attention on what is being done (Basri, 2014). Based on the explanation, the researchers felt that there was a need to do research on the description of the concentration level of learning in the Nursing Faculty of Padjadjaran University which is part of the current generation of $\mathrm{Z}$.

\section{Research Method}

This research used the descriptive quantitative research design. The variable in this study was the level of concentration of learning in Nursing Faculty students at Padjadjaran University. The study population was 597 nursing students from Padjadjaran University that divided into 4 classes (2014, 2015, 2016, and 2017). Samples were 240 students determined using the Slovin formula. The sampling technique used was proportionate stratified random sampling, the number of respondents in the class of 2014 was 68 respondents, class of 2015 was 52 respondents, class of 2016 was 56 respondents, and class of 2017 as many as 64 respondents. The instrument in this study was the learning concentration questionnaire developed by Pratiwi (2017). The instrument 
Asti Hanifah: Learning Concentration Level of Students

consisted of 18 questions including aspects of concentration in the learning process, activeness in the learning process, enthusiasm in following the learning process, and calmness in the learning process. The scores on the learning concentration questionnaire were measured using the Likert Scale (1$4)$. The value of each question was given according to the type of question (favorable and unfavorable) with the opposite score.

The final score obtained from the sum of the scores of all questions. The final score was categorized into three categories, namely:

a. High, if the total score is $>54$

b. Medium, if the total score is $44-54$

c. Low, if the total score is $<44$

Data were analyzed using univariate analysis and presented in the form of frequency distribution tables. The results of the study described using tables.

\section{Research Results}

Table 1 Level of Learning Concentration in Nursing Faculty Students of Padjadjaran University $(\mathrm{n}=\mathbf{2 4 0})$

\begin{tabular}{|c|c|c|}
\hline Category & $f$ & $\%$ \\
\hline Low & 40 & 16.7 \\
\hline Moderate & 166 & 69.2 \\
\hline High & 34 & 14.2 \\
\hline
\end{tabular}

Table 2 The Level of Learning Concentration in Faculty Nursing Students Universitas Padjadjaran, according to the Characteristic of Respondents $(n=240)$

\begin{tabular}{|c|c|c|c|c|c|c|}
\hline \multirow[t]{2}{*}{ Characteristic } & \multicolumn{2}{|c|}{ Low } & \multicolumn{2}{|c|}{ Moderate } & \multicolumn{2}{|c|}{ High } \\
\hline & f & $\%$ & f & $\%$ & f & $\%$ \\
\hline \multicolumn{7}{|l|}{ Ages } \\
\hline 18 years & 5 & 2.1 & 16 & 6.7 & 8 & 3.3 \\
\hline 19 years & 4 & 1.7 & 40 & 16.7 & 9 & 3.8 \\
\hline 20 years & 9 & 3.8 & 44 & 18.3 & 7 & 2.9 \\
\hline 21 years & 12 & 5.0 & 41 & 17.1 & 4 & 1.7 \\
\hline 22 years & 10 & 4.2 & 25 & 10.4 & 6 & 2.5 \\
\hline \multicolumn{7}{|l|}{ Gender } \\
\hline Males & 7 & 2.9 & 29 & 12.1 & 3 & 1.3 \\
\hline Females & 33 & 13.8 & 137 & 57.1 & 31 & 12.9 \\
\hline \multicolumn{7}{|c|}{$\begin{array}{l}\text { The number of social media } \\
\text { accessed }\end{array}$} \\
\hline 1 & 1 & 0.4 & 1 & 0.4 & 0 & 0 \\
\hline 2 & 0 & 0 & 9 & 3.8 & 1 & 0.4 \\
\hline 3 & 33 & 13.8 & 121 & 50.4 & 24 & 10 \\
\hline 4 & 3 & 1.3 & 24 & 10 & 7 & 2.9 \\
\hline 5 & 2 & 0.8 & 9 & 3.8 & 1 & 0.4 \\
\hline 6 & 0 & 0 & 1 & 0.4 & 1 & 0.4 \\
\hline 7 & 0 & 0 & 1 & 0.4 & 0 & 0 \\
\hline 8 & 1 & 0.4 & 0 & 0 & 0 & 0 \\
\hline
\end{tabular}


Asti Hanifah: Learning Concentration Level of Students

\begin{tabular}{lcccccc}
\hline \multirow{2}{*}{ Characteristic } & \multicolumn{2}{c}{ Low } & \multicolumn{2}{c}{ Moderate } & \multicolumn{2}{c}{ High } \\
\cline { 2 - 7 } & f & $\mathbf{\%}$ & f & \% & f & \% \\
\hline The number of devices & & & & & & \\
1 & 21 & 8.8 & 84 & 35.0 & 7 & 2.9 \\
2 & 18 & 7.5 & 79 & 32.9 & 27 & 11.3 \\
3 & 1 & 0.4 & 3 & 1.3 & 0 & 0 \\
The duration (hours) & & & & & & \\
$1-3$ & 2 & 0.8 & 16 & 6.7 & 3 & 1.3 \\
$4-6$ & 17 & 7.1 & 75 & 31.3 & 15 & 6.3 \\
$>6$ & 21 & 8.8 & 75 & 31.3 & 16 & 6.7 \\
\hline
\end{tabular}

Table 3 Comparison of Aspect Levels of Student Learning Concentration

\begin{tabular}{lllll}
\hline \multicolumn{1}{c}{ Subcategory } & Mean & SD & Min & Max \\
\hline Concentration in the learning process & 13.68 & 1.798 & 8 & 18 \\
Activeness in the learning process & 13.04 & 2.094 & 7 & 18 \\
Enthusiasm in following the learning process & 10.93 & 1.596 & 7 & 16 \\
Calmness in the learning process & 11.37 & 1.417 & 7 & 15 \\
\hline
\end{tabular}

The results of the study on the description of the concentration level of learning in Nursing students at Padjadjaran University showed that only $14.2 \%$ of students had high concentration levels while $69.2 \%$ had moderate concentration levels.

The results of cross-tabulation of the concentration level of learning in Nursing students of Padjadjaran University based on the characteristics of the respondents. Table 2 shows that the low level of learning concentration is found in women students, aged 21 years, accessing three types of social media, using one internet-based facility, and using internet of more than 6 hours per day. For the moderate level of learning concentration, there were more female respondents, 20 years old, accessing three types of social media, using one internet-based facility, and the frequency of use was 4-6 hours or more than 6 hours per day. Meanwhile, the high level of learning concentration was identified in the group of female students, aged 19 years, using two internet-based facilities with a duration of use of more than 6 hours per day. In all categories of learning concentration levels, students tend to access at least three types of social media.

Table 3 shows that the average comparison of aspects of the concentration level of learning. The highest aspect is the statement focusing attention during the learning process with a value of 13.68. While the lowest average is in the aspect of enthusiastic statements in following the learning process with a value of 10.93 .

\section{Discussion}

The average learning concentration score in Nursing Faculty students of Padjadjaran University is 49.02 with a minimum total score of 33 and a maximum of 63 . The results of the study concentration level show that a small proportion (less than 20\%) of students have low and high learning concentration, and mostly at the moderate level. The results of this study inline with previous studies related to the concentration of learning conducted by Pratiwi (2017) in students in Yogyakarta $(n=91)$ found $73.6 \%(n=67)$ of students at moderate learning concentration levels. The higher the score, the higher the concentration level of learning, the better the ability to focus attention, and the focus when learning. Conversely the lower the score obtained, the lower the concentration level of learning 
means that the person has not been able to focus attention and is still easy to distract by certain things (Rachman, 2010). A small percentage of respondents with low levels of concentration have characteristics: use social media for more than six hours in one day. This can be the reason for the disruption of the concentration of learning while studying. Students usually begin to concentrate less on learning and if it is not controlled, the intensity of social media use will be longer.

According to the characteristics of the $\mathrm{Z}$ generation population in the Nursing Faculty of Padjadjaran University, using a gadget or device is not related to the level of concentration of student learning. In contrast, Rahmayani (2017) says that one of the factors that influence the concentration of learning is the use of mobile phones. Similar to Rahmayani (2017), the results of Calderwood's research, L.Ackerman, and Conklinb (2014) revealed that excessive multitasking behavior by students caused several conflicts in the focus of learning. In this study, there is a possibility that nursing students are still able to manage the time of social media usage even though the average duration of social media usage is 4-6 hours.

Based on the duration of social media usage, it was found that 75 students accessed social media for 4 to 6 hours per day. This condition is a category that must be watched out to prevent being a heavy user category. Levine's research, et al. (2007) explains that the length of time spent on accessing social media by adolescents was significantly related to the disruption of academic tasks and the learning process. In this study, 16 students (less than 10\%) were identified who accessed social media and the internet for more than six hours in one day and had a high level of concentration. This is supported by research (Hamzah, 2015) that social media used in schools was not all bad but as a learning media. It can be concluded that the use of social media does not always have a negative impact on student learning concentration.

According to the aspect of the concentration level of learning, the aspect of focusing on the learning process was the highest average aspect. This shows that the high level of concentration of learning is influenced by the ability of students to focus attention during the learning process and enthusiasm in learning. This is in accordance with the research conducted by Rahmayani (2017) which revealed that concentration is influenced by internal and external factors such as motivation, environment, and gadgets. This means that the gadgets used to access the internet in the learning process divert students' attention and enthusiasm to the learning process.

\section{Conclusion}

It can be concluded that only a small proportion of the $\mathrm{Z}$ generation population in the Nursing Faculty have high or low concentration levels, the average student at the moderate concentration level. Students who are at the concentration level are students who use the gadget for more than 4 hours and have 3 social media. This research is expected to provide information to the education authorities to make rules regarding the use of gadgets in the learning process so that student concentration in learning will be optimal.

\section{References}

Calderwood, C., L. Ackerman, P., \& Conklinb, M.E. (2014). What else do college students "do" while studying?: An investigation of multitasking. Computers and Education, 75, 19-29. https://doi.org/https:// doi.org/10.1016/j.compedu.2014.02.004.

Hakim, T., \& Florencia, B.S. (2003). Mengatasi gangguan konsentrasi: Plus teknik-teknik latihan konsentrasi (II). Jakarta: Puspa Swara.

Hamzah, R.E. (2015). Penggunaan media sosial di kampus dalam mendukung pembelajaran pendidikan.

Lancaster, L.C., \& S. (2002). When generations collide. New York: NY: Harper Collins Inc.

Levine, L.E., Waite, B.M., \& Bowman, L.L. (2007). Electronic media use, reading, and 
Asti Hanifah: Learning Concentration Level of Students

academic distractibility in college youth, 10(4), 560-567. https://doi.org/10.1089/ cpb.2007.9990.

Pratiwi, W. (2017). Hubungan derajat insomnia dengan konsentrasi belajar Mahasiswa Program Studi Ilmu Keperawatan di Yogyakarta, 1(2), 9-15.

Rachman, M. T. (2010). Perbandingan tingkat konsentrasi belajar siswa. Skripsi. Universitas Pendidikan Indonesia.

Rahmayani, D. (2017). Faktor-faktor yang mempengaruhi konsentrasi belajar pada Mahasiswa Program Studi Ilmu Keperawatan Universitas Muhammadiyah Yogyakarta. Universitas Muhammadiyah Yogyakarta.

Sari, M.I., \& Lisiswanti, R. (2017). Manajemen waktu pada mahasiswa: Studi kualitatif pada Mahasiswa Kedokteran Universitas Lampung (Time management in students: Qualitative studies in Medical
Students University of Lampung).

Sudrajat, A. (2012). Generasi Z dan implikasinya terhadap pendidikan. Retrieved from https://akhmadsudrajat. wordpress.com/2012/10/05/generasi-z-danimplikasinya-terhadap-pendidikan/.

Tapscott, D. (2008). Grown up digital: how the net generation is changing your world.

Wang, Q., Chen, W., \& Liang, Y. (2011). The effects of social media on college students. RSCH5500-Research \& Analysis, 13. https:// doi.org/10.1111/j.1548-1379.2010.01107.x

Young, K. S. (2017). Kecanduan internet. Jakarta.

Zuhra, W. U. N. (2017). Kelahiran generasi $Z$, kematian media cetak. Retrieved from https://tirto.id/kelahiran-generasi-zkematian-media-cetak-ctLa. 